\section{For Love of Insects}

By Thomas Eisner. 2003. The Belknap Press of Harvard University Press. Cambridge, Massachusetts. 448 pages. Paper.

I remember well being almost overcome with wafts of formic acid after breaking apart an old black spruce stump during a stroll in the forests of eastern Newfoundland. At the time I figured that I was the victim of an ant species of the subfamily Formicinae, ants that Eisner describes as "spray gun(s) on legs." Such ants, each containing a formic acid gland, can eject a fluid that may exceed 50 percent formic acid. Put hundreds of such ants together in one spruce stump and the chemical barrage can be overwhelming.

A self-described "incorrigible entomophile," Thomas Eisner, Schurman Professor of Chemical Ecology at Cornell University, has written a feast of a book. In astonishing detail and delight, he describes a host of insects and arthropods and the myriad ways in which different species have evolved sophisticated chemically-based means of predation, protection, mating, and a host of other interactions among insects or between insects and plants.

Eisner's early passion for the natural history of insects combined with his interest in natural chemistry led to his pioneering advances in the chemical ecology of insects and arthropods. Chemical ecology came to be his life-long passion as he delved into the secret lives of insects mediated by a host of chemical signals. The beginnings of potential research projects were often formulated during his favourite walks in nature, particularly in the southern and southwestern United States. These initial observations often led to further sophisticated chemical studies on the identity and mechanism of the chemical basis of insect behaviour.

The book is a feast of stories about insects and their wonderfully adaptive chemicals that allow them to live and survive what is obviously a precarious existence. Each story is adorned with fascinating photos (many from the adept hands of Eisner himself) of a world seldom seen or appreciated by most of us.

These stories of insects and their chemical ecology are wonders and gems in themselves. Of equal or even greater delight, is the sense of wonder and love communicated by Eisner throughout the book's pages. By self admission, the study of nature for this naturalist explorer can never disappoint him. His passion is infectious. His stories are peppered with the joy and exhilaration of research and discovery. The reader is introduced not simply to facts and explanations, but to a host of graduate students, post-docs, and collaborators, including his wife Maria, who shared the joy and delight of Eisner in his "love of insects."

Eisner ends his work by noting that without curiosity, without passion for discovery, nature cannot endure. He laments our steady encroachment upon nature, upon the loss of boundaries. He notes, however, that ultimately, curiosity will be sustained - and that we will coexist with the living world. Can love of insects make a difference Eisner wonders? He ends this treasure of a book by admitting that he would like to believe that it does. I could not agree more.

JOHN MCCARTHY

P.O. Box 1238, (Station Main) Guelph, Ontario N1H 6N6 Canada

\section{Rare Bird: Pursuing the Mystery of the Marbled Murrelet}

By Maria Mudd-Ruth, 2005. Holtzbrinck Publishers, 175 Fifth Avenue, New York, New York 10010. 298 pages. US\$16.29.

This well-written environmental history book captures a fascinating story: the Marbled Murrelet, a seabird nesting mostly in trees: one of the greatest environmental failures in the conservation history of globalization, western civilization and North American governmental stewardship. The book states that since 1830 due to logging of the old-growth forest unsustainable activities in the Pacific Northwest has spared only $10 \%$ of the historic nesting habitat of the Marbled Murrelet. Other well-documented threats for Marbled Murrelets in this book, are fisheries (gill net by-catch) and oil pollution. That this species is covered by the U.S. Endangered Species Act (ESA) is a controversial topic because, in areas around Seattle and north of it, it is among the most abundant birds almost year round.

The book reads well and can be recommended to naturalists, arm-chair explorers as well as to conservationists, ornithologists, Marbled Murrelet activists, and researchers. Its great strength is its documentation of the recent history of Marbled Murrelet research in the United States, in California, Oregon and Washington. Also, an archeological and native view from the Haida and Tlingit tribes is presented, including fascinating stories about specimen and egg collections now distributed world-wide (e.g. in museums of London and Vienna). Accounts of famous explorers and early naturalists in "Marbled Murrelet land" such as Latham, Gmelin, Banks, Pennant, Lever, Cantwell, Dowell and Jewett are included as well.

The text reads like a detective story: The toenail of the Marbled Murrelet is as well covered as the first official nest found in 1974 near San Francisco by H. Foster. Other fascinating details cover a Canadian nest encountered 1953 by W. Feger, how S. Sealy initiated the first Marbled Murrelet studies in North America, and Russian scientist S. Kishchinskii's theory of juveniles leaving the nest to the remote ocean by simply following a stream. Insights are provided on how the International Council for Bird Preservation accepted Marbled Murrelets as a conservation issue of global 
importance. And the reader will enjoy to learn why Ridgway's colour code matters for Marbled Murrelets, why K. Nelson converted from studying woodpeckers to Marbeled Murrelets, about T. Hamer's infamous eggshell surveys, and the pioneering work by S. Sealy's student H. Carter. But it also deals with a heroic description of the many unfunded Marbled Murrelet pioneers that went to promote science in the public conservation battle, or simply to advance ornithological knowledge. The book makes clear that one nesting tree alone can fetch $\$ 100000$, resulting in huge sums being at stake when many hectares of forest are up for public discussion for potential logging. These high values explain the subsidized heli-logging of Marbled Murrelet habitat on steep slopes at high elevations.

The book handles the conservation failures for the Marbled Murrelet well, specifically the ones from the many governmental agencies involved (the reason why this book had to be written in the first place). Author Mudd-Ruth presents these shortcomings with great skill, such as the early failures of the U.S. Fish and Wildlife Service (did not carry out surveys) and U.S. Forest Service (ignored habitat inventories). But besides the notorious Bureau of Land Management and even the National Park Service, one could easily extend these shortcomings to the suite of state agencies such as Departments of Game, Natural Resources, Parks and Recreation, and certainly Forestry. And since oceans are directly involved in this topic, the National Institute of Marine Fisheries, the National Oceanic and Atmospheric Administration, the National Sanctuaries and the U.S. Navy all get to carry the blame as well. The Canadian side involves at least the Canadian Wildlife Service, the Department of Fisheries and Oceans, the British Columbia Ministries of Forestry and Environment, Parks Canada, and the Mineral Management Service. The Marbled Murrelet swims with steadily declining numbers in all of these "governmental waters", as well as in the industrial and private ones. And almost all of these agencies have a noted Marbled Murrelet conservation history, and some, to this very day, are doing nothing of relevance to resolve the Marbled Murrelet problem.

It becomes clear from this book that these institutions do not provide relevant public guidance and high quality data for sustainable decision-making, and addressing the inherent conflict between endangered species, economic growth and development. Are the existing administrative structures and the reward and promotion systems for the staff of these agencies really able to manage such problems at all?

The author mentions a lot the Pacific Seabird Group (PSG), which is involved as a lobby and expert group for Marbled Murrelets. However, the PSG is not a legal governmental body and can only compile and provide suggestions. To this very day we have no high quality old-growth inventory layer relevant to Marbled Murrelet habitat and sustainable management of the precious forest; nor do we even have any relevant studies and data collected throughout its range on the food items of Marbled Murrelets; e.g., Sand Lance. As this powerful book outlines, the Pacific Northwest Forest plan created 1994 by the Clinton administration has improved the Marbled Murrelet management at least for the states of the lower 48 .

The book makes the tensions around the Marbled Murrelet situation explicitly clear: In 1989 the Marbled Murrelet was suggested as a candidate species for the ESA. However, it took three more years. When the Audubon Society of Portland sued the U.S. Fish and Wildlife Service the bird eventually received a status in 1992 federally listed as a threatened species; when it was the recovery process could start. The status review of this endangered species is due every five years, but as the reader will learn, it has been delayed from 1997 til 2002 when eventually a timber industry group took the government to court. Another classic "MaMu" legal case is presented with the influential court case from 1993 "Marbled Murrelet vs. Pacific Northwest" where EPIC (Environmental Protection Information Center) sued Pacific Lumber.

Further, as well-presented in this book, Marbled Murrelets live in a complex habitat; e.g., where one of the biggest marihuana grower industries in the western world makes its (illegal) living. Raven populations in the Pacific Northwest have increased 15-fold: a human subsidized Marbled Murrelet nest predator. Habitat fragmentation is severe, and the outlook is very bleak, as the loss of Redwoods shows for instance.

This book could have been improved if the Russian and Canadian populations were explained and elaborated on in more detail: their story is as exciting and as full of tensions as the U.S. one and inclusion would provide a complete context. Most relevant Canadian researchers and very influential players are not named and elaborated on in this book, such as I. Manly, V. Bahn, G. Kaiser, A. Derocher, F. Cooke, A. Burger. This book also has no maps (but nice black and white figures by Paul Jones). It was the Canadians who solved one of the biggest technical problem in the study of this bird: being able to catch it. The brood patch story presented in this book was already revised when this book was written and by Canadian researchers who the author quotes. The Canadian Clayoquot Sound (just north of Seattle), the location of a major environmental conflict and Canada's largest mass-arrest in history, is hardly mentioned at all.

The book explains that more than 3000 trees have been climbed in order to find the elusive nests, but less than 61 known nests are reported in this book (likely, one has climbed trees and searched in the wrong field sites and habitats). This leads me to a more serious flaw in this book. The author chose to ignore the known nests and findings; e.g., as presented at PSG meetings at which the author personally was present and referred to and cites in the text. Marbled Murrelet nests are actually located across elevations and on steep slopes, which will modify the conservation pressure on habi- 
tats. The reader is advised to adjust the nest site image presented in this book at the following website by the Center for Wildlife Ecology http://www.sfu.ca/biology/ wildberg/mamuweb/welcome.htm where over 120 nests are presented to the public.

Unfortunately, this book does not document that "low elevations" alone does not sufficiently describe the nesting habitat. It does not deal with how the myth of low elevation old-growth forest evolved in the first place, and why this myth remains active within the conservation community to this very day. The book reports an uncommented figure for 10 s of millions of Marbled Murrelets in Alaska alone; this must be way too high by the factor 10 .

\section{BOTANY}

\section{Canada's Forests: A History}

By Ken Drushka. 2003. Forest History Society Issues Series. McGill-Queen's University Press, Montreal and Kingston. 97 pages. Paperback. \$12.95 Can.

This treatise was written by a journalist, now deceased, who had considerable practical experience in the forest industry, having worked as a logger in British Columbia. It is highly readable, being targetted at the nonspecialist, with few references or supporting data. Even so, it provides considerable food for thought in a compact format. The treatise presents a generally positive picture of Canadian forests and the forest industry. Ken Drushka states his premises boldly: "Canadian forests still exist virtually intact. Since European colonization ... only about 6 percent of Canada's forest land has been converted to other uses" (page vii). Moreover, "it is inaccurate and misleading to claim that the country's forests are in the process of being destroyed, devastated, decimated, or damaged beyond recovery" (page 82). On the contrary, Drushka considers that, by and large, "they are whole and healthy" (page 82). This is certainly a view markedly at variance with that usually presented through the popular media.

Drushka develops his views in five chapters, focussing on "The Canadian Forest", "Early Forest Use", "Industrialization of the Forests", "The Rise of Forest Conservation", and "Sustainable Forest Management", which includes a brief survey of the state of Canada's forests as of year 2000. The survey covers a lot of ground (pun intended!) and, as might be expected, the treatment of topics is somewhat uneven and often cursory. I found the summary of the postglacial assembly of "The Canadian Forest" especially unsatisfactory. Also in this opening chapter, Drushka sets the scene by identifying and describing eleven modern forest regions across Canada, although only ten are shown on the accompanying map. Following this introduction, his historical survey in the next four chapters is basically chronological and sequential.

Drushka notes that the Canadian landscape has been home to people throughout postglacial time and that
No doubt, the peculiar efforts by the current U.S. government administration trying to de-list this species from the ESA and against all efforts of most biologists will keep this well written and very readable book in high demand. It's the first of its kind for the Marbled Murrelet, and a great description for the state-of-theart of the environment and conservation in arguably one of the most powerful countries in the world.

FALK HuETtManN

Biology and Wildlife Department, Institute of Arctic Biology, 419 Irving I, University of Alaska, Fairbanks, Alaska 99775-7000 USA

Aboriginal people "had an often-significant impact on the forests" (page 17). He points out that Aboriginal people used fire as a land management tool. I found it refreshing to see an environmental history which acknowledges that Canada had a human history before European settlement. Drushka identifies the first major impetus for sustained forest use as the establishment of the fishing industry in Newfoundland in the 1500s. Interestingly, he does not highlight the fur trade as a major reason for forest clearance, pointing out that permanent settlement by Europeans was actively discouraged by the trading companies. He sees the main phase of European settlement, beginning in the seventeenth century, being associated with "serious and mostly negative impacts on the forests" (page 23), as land was cleared for agriculture and wood was used as the principal fuel for winter heating. Commercial exploitation of the forests began in the late seventeenth century, propelled by warfare and conflicts that stimulated Britain particularly to turn to Canada as a source of supply for timber. The exploitation front moved westward and inland from the east coast to interior Canada, primarily along the major waterways, following a similar pattern to settlement. Drushka traces the establishment of administrative policies that made the forestry industry a major source of government revenue, especially later at the provincial level.

In the third chapter, Drushka examines more closely the industrialization of the forest industry through the latter part of the nineteenth century. He considers that the spread of transportation networks, especially the railway, had a triple effect on the forest industry. First, railway construction consumed large amounts of timber. Second, better transport networks encouraged the spread of lumbering to previously economically inaccessible regions. Third, the wood-burning steam locomotives themselves demanded large quantities of timber as fuel. Clear-cutting became common. Drushka points out that the spread of lumbering went hand-in-hand with devastating wildfires that spread through the remaining slash on clear-cuts, often start- 